\title{
Molecular and morphological approaches for species delimitation and hybridization investigations of two Cichla species
}

\author{
Andrea A. F. Mourão', Diogo Freitas-Souza², Diogo T. Hashimoto' ${ }^{3}$ Daniela C. Ferreira ${ }^{4}$, Fernanda D. do \\ Prado $^{5}$, Rosicleire V. Silveira ${ }^{5}$, Fausto Foresti \& Fábio Porto-Foresti ${ }^{1}$
}

\begin{abstract}
1. Departamento de Ciências Biológicas, Faculdade de Ciências, Universidade Estadual Paulista (UNESP), Av. Eng. Luiz Edmundo Carrijo Coube, 14-01, Vargem Limpa, 17033-360 Bauru, SP, Brazil. (mouraoaaf@ibb.unesp.br; fpforesti@fc.unesp.br)

2. Departamento de Morfologia, Instituto de Biociências, Universidade Estadual Paulista (UNESP), Distrito de Rubião Junior, s/n, Distrito de Rubião Junior, $18618-970$ Botucatu, SP, Brazil. (souza.d.freitas@gmail.com; fforesti@ibb.unesp.br)

3. Centro de Aquicultura da UNESP, Campus de Jaboticabal, Universidade Estadual Paulista (UNESP), via de Acesso Prof. Paulo Donato Castellane, s/n, Vila Industrial 14884-900 Jaboticabal, SP, Brazil. (diogo@caunesp.unesp.br)

4. Departamento de Biologia e Zoologia, Instituto de Biociências, Universidade Federal de Mato Grosso (UFMT), Av. Fernando Corrêa da Costa, 2367, Boa Esperança, 78060-900 Cuiabá, MT, Brazil. (ferreiradc@gmail.com)

5. Departamento de Biologia e Zootecnia, Campus de Ilha Solteira, Universidade Estadual (UNESP), Rua Monção, 226, Zona Norte, 15385-000 Ilha Solteira, SP, Brazil. (rosiverissimo@bio.feis.unesp.br)
\end{abstract}

\begin{abstract}
The hybridization is a widely-discussed issue in several studies with fish species. For some authors, hybridization may be related with diversification and speciation of several groups, or also with the extinction of populations or species. Difficulties to differentiate species and hybrids may be a problem to correctly apply a management of wild species, because hybrid lineages, especially the advanced ones, may resemble the parental species. The genus Cichla Bloch \& Schneider, 1801 constitutes an interesting experimental model, considering that hybridization and taxonomic uncertainties hinder a correct identification. Considering these problems, in this study, we developed genetic methodologies and applied meristic and morphometric approaches in wild samples in order to identify species and for test a possible hybridization between Cichla kelberi Kullander \& Ferreira, 2006 and Cichla piquiti Kullander \& Ferreira, 2006. For this, C. kelberi, C. piquiti and potential hybrid (carijó) individuals were collected in Paraná and Tietê rivers (SP, Brazil). For meristic and morphometric methods, the individuals were analyzed using the statistical software Pcord 5:31, while for molecular methods, primers for PCR-multiplex were designed and enzyme for PCR-RFLP were selected, under the species-specific nucleotide. All results indicated that the carijó is not an interspecific hybrid, because it presented identical genetic pattern and morphology closed to C. piquiti. Thus, we propose that carijó is a C. piquiti morphotype. In addition, this study promotes a new molecular tool that could be used in future research, monitoring and management programs of the genus Cichla.
\end{abstract}

KEYWORDS. Cichla kelberi; Cichla piquiti; carijó; Cluster Similarity; PCA; PCR-multiplex.

RESUMO. Abordagens morfológicas e moleculares para delimitação de espécie e investigações de hibridação de duas espécies de Cichla. A hibridação é uma questão amplamente discutida em vários estudos com espécies de peixes. Para alguns autores, hibridações podem estar relacionadas à diversificação e especiação de muitos grupos, ou à extinção de populações ou espécies. Dificuldades para diferenciar espécies e híbridos podem ser um problema para aplicar corretamente o manejo de espécies selvagens, porque linhagens híbridas, especialmente as mais avançadas, podem assemelhar-se aos parentais. O gênero Cichla Bloch \& Schneider, 1801 constitui um interessante modelo experimental, considerando que a hibridação e as incertezas taxonômicas dificultam a correta identificação. Considerando estes problemas, neste estudo foram desenvolvidas metodologias genéticas e aplicadas abordagens merísticas e morfométricas em amostras selvagens para identificar espécies e para testar uma possível hibridação entre Cichla kelberi Kullander \& Ferreira, 2006 e Cichla piquiti Kullander \& Ferreira, 2006. Para isto, C. kelberi, C. piquiti e indivíduos do híbrido em potencial (carijó) foram coletados nos rios Paraná e Tietê (SP, Brasil). Para os métodos merístico e morfométrico, os indivíduos foram analisados, utilizando-se o software estatístico Pcord 5:31, enquanto que para os métodos moleculares, primers para PCR-multiplex foram desenhados e enzimas para PCR-RFLP foram selecionadas, sob nucleotídeos espécie-específicos. Todos os resultados indicaram que o carijó não é um híbrido interespecífico, porque apresentou padrão genético idêntico e morfologia próxima à $C$. piquiti. Assim, propomos que o carijó é um morfotipo de $C$. piquiti. Além disso, este estudo promove uma nova ferramenta molecular que poderá ser utilizada em futuras pesquisas, monitoramento e manejo do gênero Cichla.

PALAVRAS-CHAVE. Cichla kelberi; Cichla piquiti; carijó; Análise de agrupamento; PCA; PCR-multiplex.

The most influent species concept was proposed by MaYr (1942, 1963) (HAuSDORF, 2011). This concept defines species as a group of individuals or a population with potential to interbreed that is reproductively isolated from other groups. However, in several cases this concept is not applicable, especially for fish species. This is because studies have been demonstrated that hybridization might occur between specimens classified as distinct species, producing fertile progeny (HASHIMOTO et al., 2012; PrAdo et al., 2011, 2012). Conceivably, the hybridization is a widely-discussed issue because it questions fundamental biological concepts, such as species definition. 
For the genus Cichla Bloch \& Schneider, 1801 the hybridization is a natural phenomenon that could be related with diversification and speciation (WILlis et al., 2012). On the other hand, for Toledo-FilHo et al. (1998) and Millar et al. (2012) introgressive hybridization may also cause gene flow between different species or lineages, and in some cases, lead populations or species to extinction (Allendorf et al., 2001). In any case, difficulties to clearly differentiate hybridization could be a problem in monitoring wild species (AlLENDORF et al., 2001). This occurs because hybrids, especially the more advanced (e.g. resulting from introgression) may be morphologically similar to the parental (Allendorf et al., 2001). Nevertheless, studies commonly perform identification of hybrids through meristic and morphological characteristics without analyzing genetic markers (SCRIBNER et al., 2001). However, the use of a unique source of analysis may lead to uncertain results (CHEvassus, 1983; MALLET, 2005).

The hybridization for the genus Cichla in natural environment has been hypothesized by numerous studies (e.g. Alves \& FeldBerg, 1998; Brinn et al., 2004; Oliveira et al., 2006). Specifically, the hybridization between Cichla kelberi Kullander \& Ferreira, 2006 and Cichla piquiti Kullander \& Ferreira, 2006 has already been analyzed using genetic approaches as SPAR technique (AlmEIDA-FERREIRA et al., 2011) and the 5S rRNA marker (OliveIRA et al., 2008). However, considering the limitations of these studies, such as the ambiguous results of the methodology SPAR and the problems to obtain species-specific markers reported by Oliveira et al. (2008), not confirming the presence of hybridization, it is necessary more studies for C. piquiti and $C$. kelberi and the supposed interspecific hybridization.

In addition to the hybridization problems there are taxonomic issues for the genus Cichla. According to Kullander \& Ferreira (2006) identification key, Cichla has 15 valid species. For these authors, Cichla kelberi is frequently identified as Cichla cf. monoculus, while C.piquiti may be misidentified as Cichla sp. However, WiLLIS et al. (2012) analyzed multi-locus data and questioned the validity of the KULLANDER \& FERREIRA (2006) identification key, rearranging these 15 species in eight evolutionarily significant units (ESUs). They also suggested C. kelberi and C. ocellaris synonymization as subspecies or distinct ESUs.

An aggravating factor for the hybridization within the genus and uncertainties concerning to taxonomic is the frequent introductions of species (AGOSTINHO et al., 2007). According to these authors, species of Cichla are appreciated in sport (Kullander, 2003) and professional fishing (SAMPAIO et al., 2012), and are also commonly introduced in non-native environments to control other invasive species (THRESHER et al., 2014). Due to this, Cichla species, naturally restricted to the Amazon basin (KULLANDER \& FerReIRA, 2006), have been frequently reported in several Brazilian basins (Pelicice \& Agostinho, 2009).

These introductions of fish, even when aiming to control invasive species, generate disturbances in several trophic levels (Godinho et al., 1994; LATINi \& Petrere
$\left.J_{R}, 2004\right)$. In general, the native ichthyofauna is affected with the presence of exotic piscivorous species, such as Cichla. For example, some studies reported a reduction or even disappearance of some species (GodinHo et al., 1994; Latini \& Petrere JR, 2004).

A problem with the introduction of species is the high proliferation and phenotypic plasticity regulated with the environment-genotype interaction (FALCONER \& MACKAY, 1996). This fact is expected for the genus Cichla, commonly known as peacock bass, due to the adaptive capacity to different environments (CARvalHo et al., 2014). Thus, Cichla species constitute interesting experimental models to studies of ecology, genetic, toxicology, parasitology and, principally taxonomy currently (KULLANDER \& FERREIRA, 2006; WILLIS et al., 2012).

Studies that provide accessible and clear molecular markers for species identification are extremely important for species conservation (Young et al., 2001). Comparative molecular markers based on the detection of mtDNA (mitochondrial DNA) and nDNA (nuclear DNA) variability and diagnostic differences may enable to identify species based on variations even in a unique nucleotide polymorphism (HАSнIмото et al., 2012), which would be taxonomically important for the group. The use of mtDNA and nDNA is important because hybrid individuals inherit nDNA from both parental but they inherit mtDNA just from maternal parental. The use of both nDNA and mtDNA markers allows to obtain a greater amount of information for species and hybrids identification (Авогм et al., 2010; НАSнIмото et al., 2010; De-Franco et al., 2012; Gomes et al., 2012; KARLSSON et al., 2012).

Considering hybridization, taxonomic problems and the frequent introductions as an aggravating factor in the genus Cichla, the development of a reliable methodology for hybrid identification is essential to assist to elucidate species identification and also to investigate the possibility of hybridization in wild stocks. In this study, we developed PCR-RFLP and PCR-multiplex methodologies based on mtDNA and nDNA for species identification. We also applied these genetic markers, meristic and morphometric analyses in wild samples in order to identify putative hybridization between $C$. kelberi and C. piquiti.

\section{MATERIAL AND METHODS}

A total of 125 individuals (both sexes, juveniles and adults) of the species $C$. kelberi (yellow peacock bass), $C$. piquiti (blue peacock bass) and individuals classified as putative hybrids of these two Cichla species (presenting a dubious external morphological identification, possible hybrids between the two-former species) were collected in Ilha Solteira (89 specimens), Rubineia (20 specimens), Pauliceia (10) and Uru (6 specimens) reservoirs in Paraná and Tietê rivers, São Paulo state, throughout the year 2009 (Fig. 1). From Ilha Solteira, 30 specimens were collected and used for meristic, morphometric and genetic analyses. Additionally, 95 specimens from Uru, Pauliceia e Rubineia 


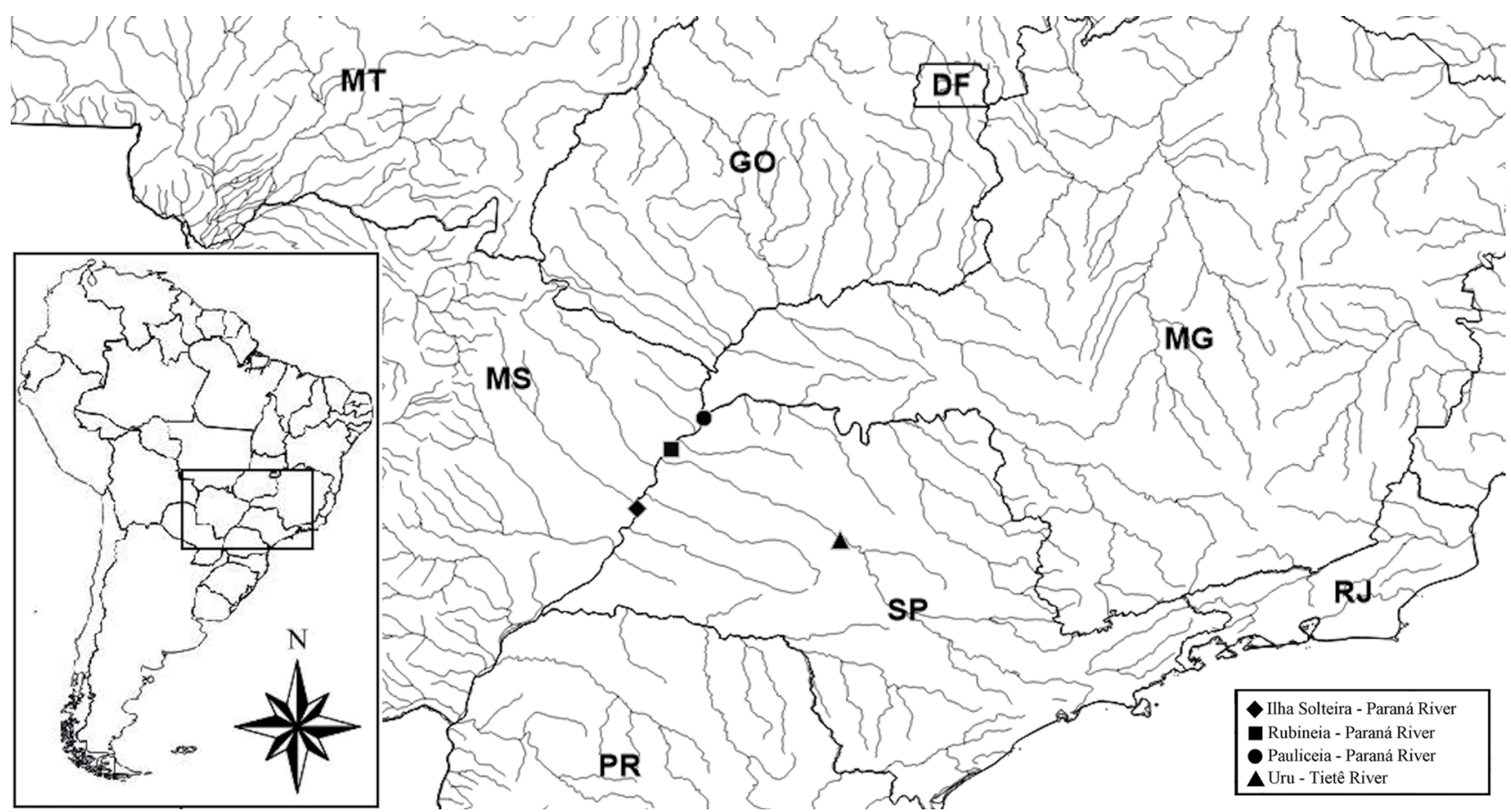

Fig. 1. Sample sites location in the Paraná and Tietê rivers, state of São Paulo, Brazil.

were collected and used for genetic analysis. The possible hybrids between $C$. kelberi and $C$. piquiti are hereafter referred as carijó. All analyses were carried out in accordance with the Code of Ethics of the World Medical Association (Declaration of Helsinki) for animal experiments. The individuals meristic and morphometrically analyzed are deposited at the Laboratório de Ictiologia, Departamento de Zoologia e Botânica (UNESP, campus São José do Rio Preto), under the voucher numbers DZSJRP 8833, 8843, 8872 and 8946 . The fin tissue samples genetically analyzed are deposited at the Laboratório de Genética de Peixes, (UNESP, campus Bauru).

For meristic and morphometric analyses, 30 specimens from Ilha Solteira were selected and analyzed in the Laboratório de Ictiologia Neotropical, according to Kullander (1986), Kullander \& NiJssen (1989) and Kullander \& Ferreira (2006) (Figs 2, 3). Body measurements were taken from point to point with a digital caliper (accuracy 0.01). Several colour characters were considered: number of vertical bars and the presence of post orbital and occipital bars, as proposed by KULLANDER \& FERREIRA (2006) (Figs 4-6). Morphometric data and their proportions (standard length and head length) were ordered using PCA. Meristic data were analyzed with a Cluster Similarity analysis (Euclidean distance). Both analyses were conducted in the statistical software Pcord 5:31 (MCCUNE \& MEFFORD, 2006).

For the genetic analysis, 125 fin tissues from all the collection sites Ilha Solteira, Rubineia, Pauliceia and Uru were sampled and DNA extractions were performed according to the commercial protocol Wizard Genomic DNA Purification Kit (Promega). DNA quantification was tested for all samples using the Qubit 3.0 Fluorometer equipment.
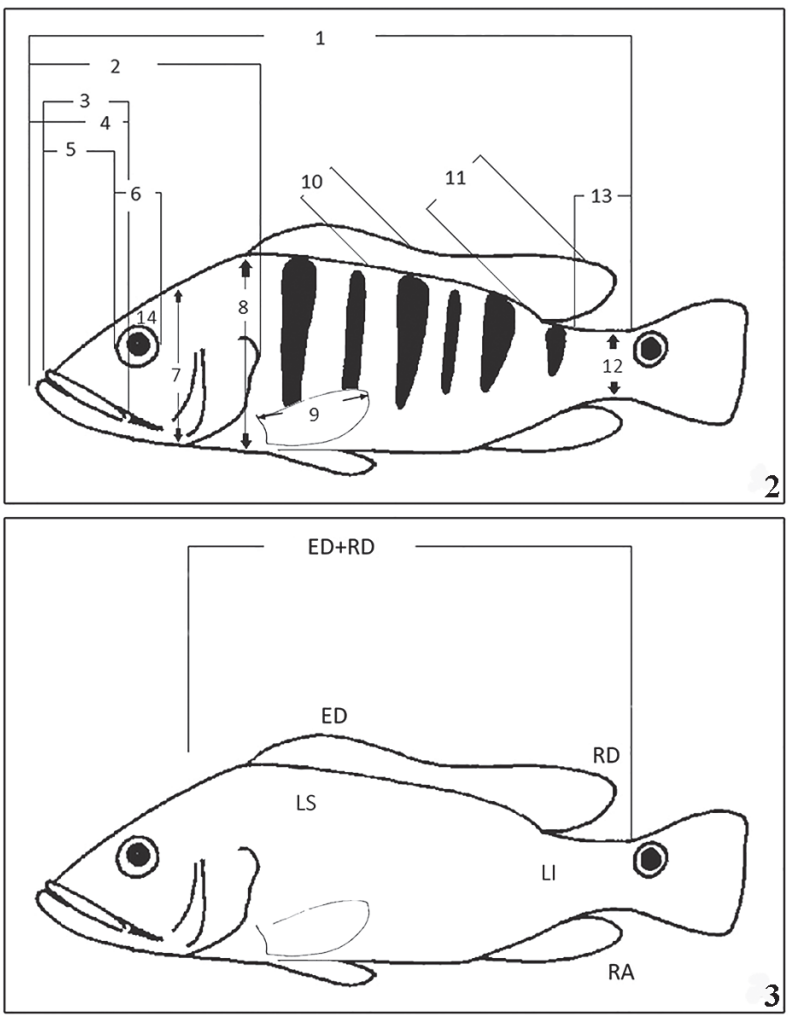

Figs. 2, 3. Fig. 2 (adapted of Kullander \& Ferreira, 2006), body measures used for morphological analyses of Cichla Bloch \& Schneider, 1801 individuals: Standard length (1); head length (2); snout length (3); length of the lower jaw (4); length of the upper jaw (5); orbit diameter (6); head height (7); body height (8); length of pectoral fin (9); length of the dorsal fin spines (10); length of the dorsal fin radius (11); length of caudal peduncle (12); caudal peduncle height (13); and inter-orbital width (14). Fig. 3 (adapted of Kullander \& Nijssen 1989): meristic parameters included the following measures. Numbers of dorsal fin spines (ED); dorsal fin radius (RD); upper lateral line scales (LS); lower lateral line scales (LI); pectoral fin radius (RP); and anal fin radius (RA). 
For PCR-multiplex (Polymerase Chain Reaction-multiplex) and PCR-RFLP (Polymerase Chain Reaction-Restriction Fragment Length Polymorphism) reactions development, the cytochrome c oxidase universal subunit I (COI) and the recombination activating 1 (RAG1) genes were amplified under the PCR conditions described (Tab. I) with the primers described (Tab. II).

In order to design species-specific primers and to assign species-specific restriction enzymes we sequenced the mtDNA gene COI and the nDNA gene RAG1 using the Automatic Sequencer ABI3130 Capillary (Perkin-Elmer). In total, 43 amplification products (11 COI gene sequences - 5 C. piquiti, 3 C. kelberi and 3 carijó and 32 RAG1 gene sequences - 11 C. piquiti, 13 C. kelberi and 8 carijó; assorted collection sites) were analyzed. Both genetic markers, primers for PCR-multiplex were designed and enzyme for PCRRFLP were selected, under the species-specific nucleotide differentiation. For this, the sequences were aligned using the ClustalW parameter (ThомPSON et al., 1994) implemented in the BioEdit software (HALL, 1999). Consensus sequences were inserted in Netprimer software (www.premierbiosoft.
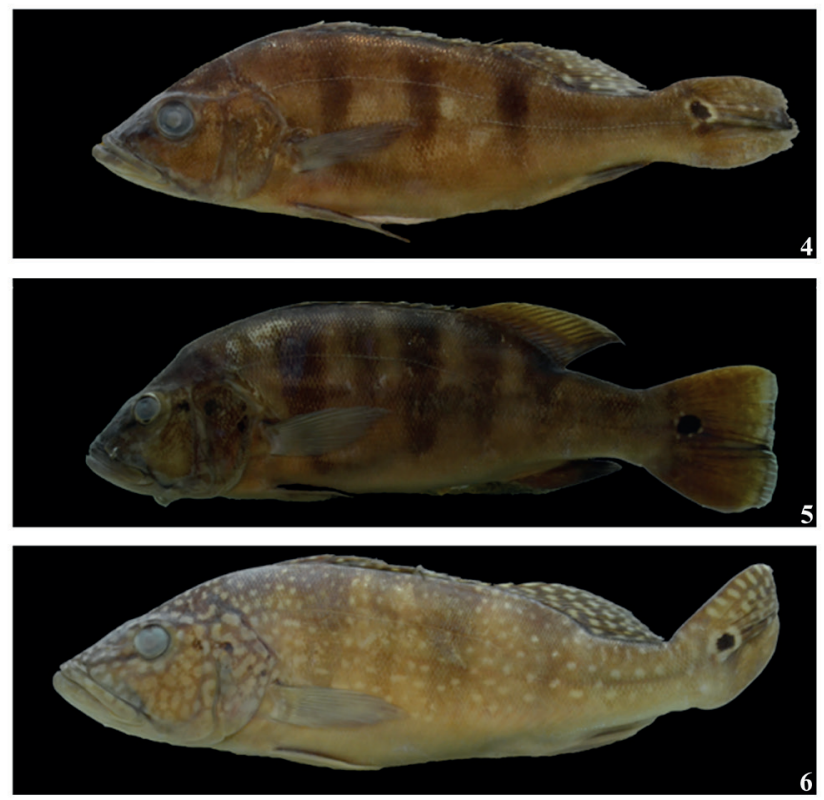

Figs 4-6. Fig. 4: Cichla kelberi Kullander \& Ferreira, 2006; Fig. 5: Cichla piquiti Kullander \& Ferreira, 2006; Fig. 6: carijó.

Tab. I. Methodologies conditions (PCR, PCR-multiplex and PCR-RFLP).

\begin{tabular}{|c|c|c|c|c|}
\hline \multicolumn{5}{|c|}{ PCR AND PCR-MULTIPLEX $(24 \mu \mathrm{L})$} \\
\hline Concentration conditions & \multicolumn{4}{|c|}{ Thermalcycle conditions } \\
\hline 1xPCR buffer & $1 \mathrm{x}$ & $5 \mathrm{~min}$ & $95^{\circ} \mathrm{C}$ & 1 cycle \\
\hline $\mathrm{MgCl} 2$ & $1.5 \mathrm{mM}$ & $30 \mathrm{~s}$ & $95^{\circ} \mathrm{C}$ & 35 cycles \\
\hline dNTP & $150 \mu \mathrm{M}$ & $30 \mathrm{~s}$ & $52^{\circ} \mathrm{C}$ & \\
\hline primers & $0.2 \mu \mathrm{M}$ & $30 \mathrm{~s}$ & $72^{\circ} \mathrm{C}$ & \\
\hline Taq polymerase & $0,5 \mathrm{U}$ & $5 \mathrm{~min}$ & $72^{\circ} \mathrm{C}$ & 1 cycle \\
\hline DNA template & $20-50 \mathrm{ng}$ & & & \\
\hline \multicolumn{5}{|c|}{ RFLP $(8 \mu \mathrm{l})$} \\
\hline Concentration conditions & \multicolumn{4}{|c|}{ Thermalcycle conditions } \\
\hline Enzyme buffer $(10 \mathrm{U} / \mu \mathrm{L})$ & $1 \mathrm{x}$ & & NlaIV & BsrI \\
\hline Enzyme (NlaIV/BsrI) & $5 \mathrm{U}$ & $60 \mathrm{~min}$ & $37^{\circ} \mathrm{C}$ & $65^{\circ} \mathrm{C}$ \\
\hline PCR product & $60 \mathrm{ng}$ & $20 \mathrm{~min}$ & $65^{\circ} \mathrm{C}$ & $80^{\circ} \mathrm{C}$ \\
\hline
\end{tabular}

Tab. II. Primers utilized in this study.

\begin{tabular}{lllc}
\hline Primers & Type & \multicolumn{1}{c}{ Sequence } & References \\
\hline COI-Fish2 F & & 5'TCGACTAATCATAAAGATATCGGCAC3' & WARD et al., 2005 \\
COI-Fish2 R & \multirow{2}{*}{ Universal } & 5'ACTTCAGGGTGACCGAAGAATCAGAA3' & WARD et al., 2005 \\
RAG1Cichla F* & & 5'GGCTCTCTGGATGGTCTTCCT3' & Present study \\
RAG1 ichla R $^{*}$ & & 5'ACACTTCYCCAATYTCATCCTGGA3' & Present study \\
\hline COI Ck F & & 5'ATGATCGGAGGCTTTGGAAAC3' & Present study \\
COI Cp F & & 5'GGTGTGTCCTCAATCCTGGT3' & Present study \\
RAG1 Ck F & Species-specific & 5'AACCCCTTTTCTGAGTCCGTA3' & Present study \\
RAG1 Cp F & & 5'TACATCTGCACTCTATGTGACTCA3' & Present study \\
\hline
\end{tabular}

com/netprimer) and species-specific primers (COI Ck F and RAG1 Ck F for C. kelberi and COI Cp F and RAG1 Cp F for C. piquiti) were designed internally to the universal primers, to produce different sizes fragments for each species (Fig. 7, Tab. II). Posteriorly, consensus sequences were inserted in the Nebcutter V2.0 software (VINCZE et al., 2003) and restriction maps were generated, thus enzymes with different cleavage patterns for each species were selected (Fig. 8).

PCR-multiplex (Tab. I) and PCR-RFLP (Tab. I) reaction conditions were standardized (performed successfully in every sample). Intraspecific variability was not detected for the analyzed loci, demonstrating that diagnostic nucleotides for each species were fixed over all the studied samples. DNA fragment sizes were determined by electrophoresis on agarose gel stained with SYBR ${ }^{\circledR}$ Safe DNA gel stain, visualized with UV illumination and images were captured by a digital camera (C-5060 5.1 Megapixel, Camedia, Olympus).

\section{RESULTS}

Results obtained from genetic analyses revealed the presence of mutational sites that differentiate Cichla kelberi 


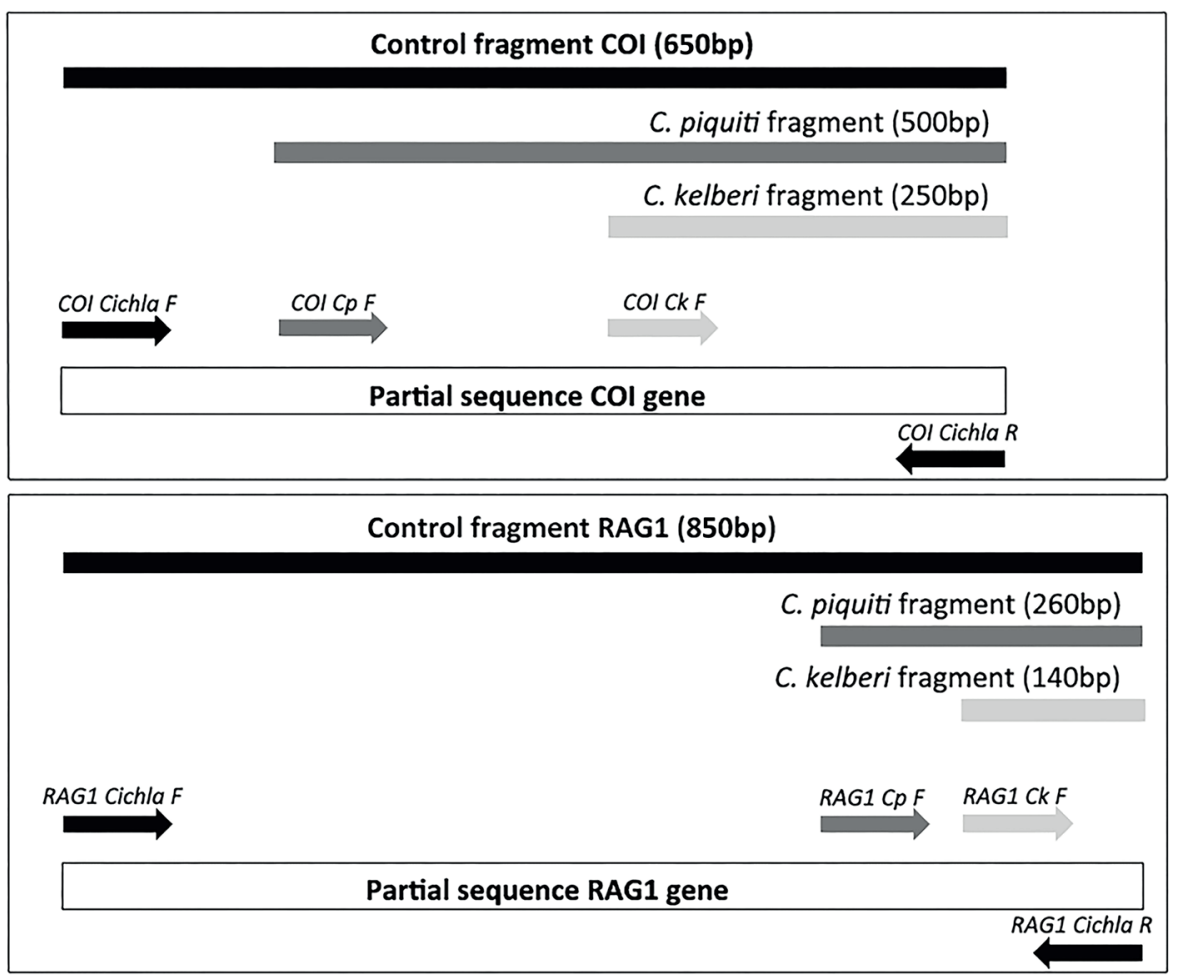

Fig. 7. Recognition and orientation sites of universal and species-specific primers within regions of the mitochondrial (COI) and nuclear (RAGI) genes of Cichla Bloch \& Schneider, 1801 species.
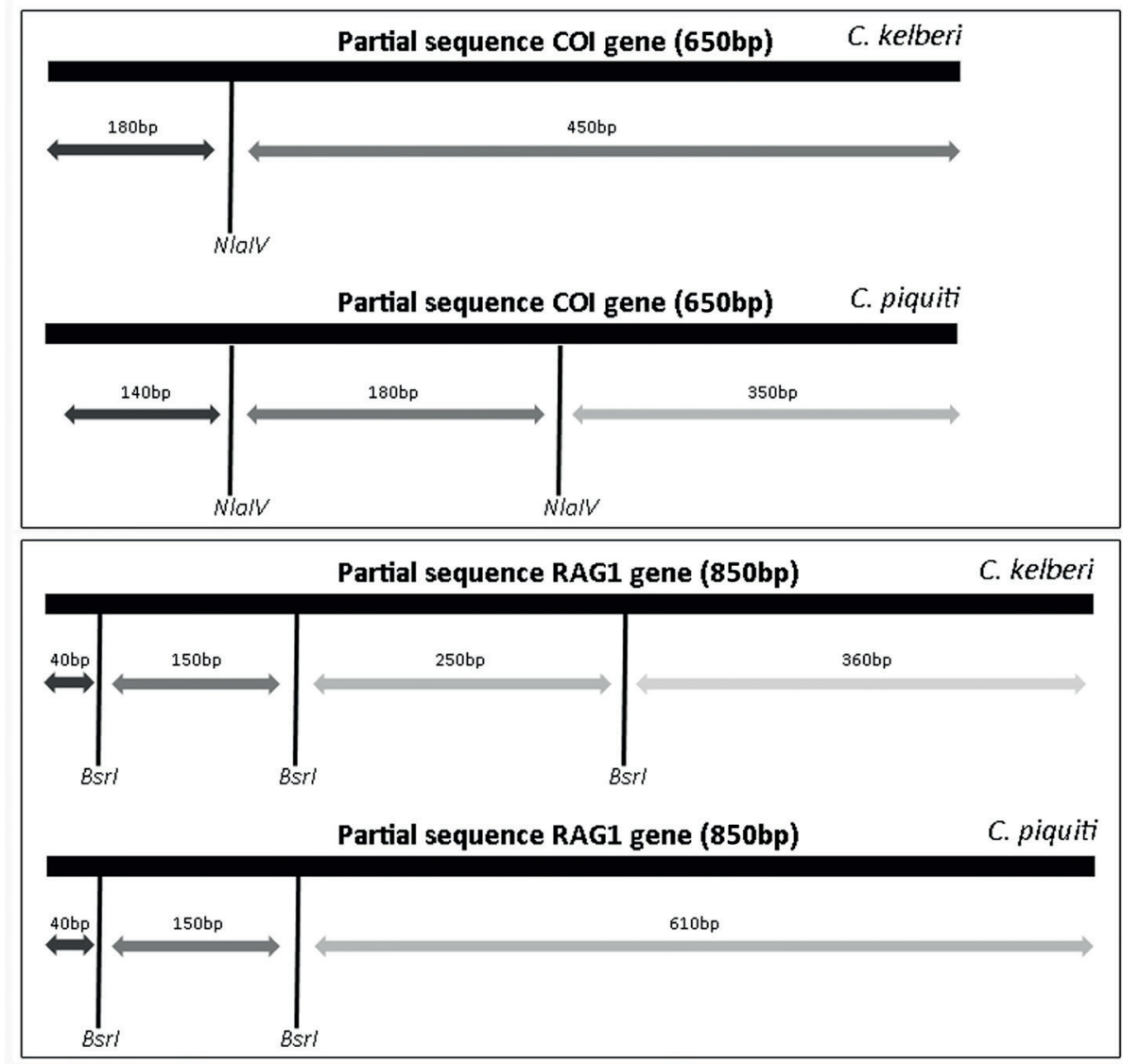

Fig. 8. Restriction maps of the COI gene and RAG1 gene for the species Cichla kelberi Kullander \& Ferreira, 2006 and Cichla piquiti Kullander \& Ferreira, 2006. 
from Cichla piquiti in all the analyzed samples, allowing the development of specific PCR-multiplex and PCR-RFLP markers of COI and RAG1 genes for species identification (Figs 7, 8; Tabs I, II).

Genetic analysis using both the PCR-multiplex and PCR-RFLP of mitochondrial and nuclear markers clearly differentiated Cichla kelberi from Cichla piquiti while the possible hybrids identified as carijó showed identical genetic patterns to C. piquiti in all the analyses (Figs 9-12). Considering details of each molecular technique, the PCRmultiplex of the COI gene (mitochondrial gene) revealed one control band of about $650 \mathrm{bp}$ in all samples and a band of almost $250 \mathrm{bp}$ for $C$. kelberi and approximately $500 \mathrm{bp}$ for C. piquiti (Fig. 9). The PCR-multiplex of the RAG1 gene (nuclear gene) revealed one control band of about $850 \mathrm{bp}$ in all samples and a band of almost $140 \mathrm{bp}$ for C. kelberi and approximately $260 \mathrm{bp}$ for $C$. piquiti (Fig. 10). The carijó individuals also presented identical bands as found in $C$. piquiti for both markers (Figs 9, 10).

The PCR-RFLP of the COI gene (mitochondrial gene) revealed fragments of almost 180 and $450 \mathrm{bp}$ for C. kelberi, while C. piquiti showed bands of approximately 140, 180 and 350bp (Fig. 11). The PCR-RFLP of the RAG1 gene (nuclear gene) revealed fragments of almost 40, 150, 250 and 360bp in C. kelberi, while for C. piquiti fragments were of approximately 40, 150 and 610bp (Fig. 12). The carijó individuals presented identical bands as found in C. piquiti for both nuclear and mitochondrial markers when using PCR-RFLP technique (Figs 11, 12).
The utilization of morphometric and meristic data proposed by Kullander \& FerReIra (2006) allowed the correct identification of the species C. kelberi, C. piquiti and the carijó individuals. Results of PCA revealed the existence of morphological differences between the analyzed individuals. The first PCA axis highlights morphological difference of $C$. kelberi in relation to C. piquiti and carijó, with the higher explanation percentage (50\%). The second PCA axis shows the morphological differences between $C$. piquiti and carijó, with a lower explanation percentage (13\%) (Fig. 13). Cluster similarity of the meristic data generated two major groups: a cluster composed mostly by C. kelberi individuals and another cluster formed entirely by the two morphotypes of $C$. piquiti (Fig. 14). Even though these characters are used as diagnostic in determining species of the genus Cichla, the existence of overlapping prevents the separation of C. piquiti and carijó.

\section{DISCUSSION}

The intermediate morphology to the C. piquiti and C. kelberi species presented by carijo individuals and the hybridization reported in previous studies for Cichla (e.g. Alves \& FeldBerG, 1998; Brinn et al., 2004; Oliveira et al., 2006, 2008; AlmeIDA-FerreIra et al., 2011) made us consider the hybridization hypothesis in this study. However, all the performed analyses do not confirm carijó individuals as an interspecific hybrid between $C$. piquiti and C. kelberi. Therefore, the findings do not support the hypothesis of
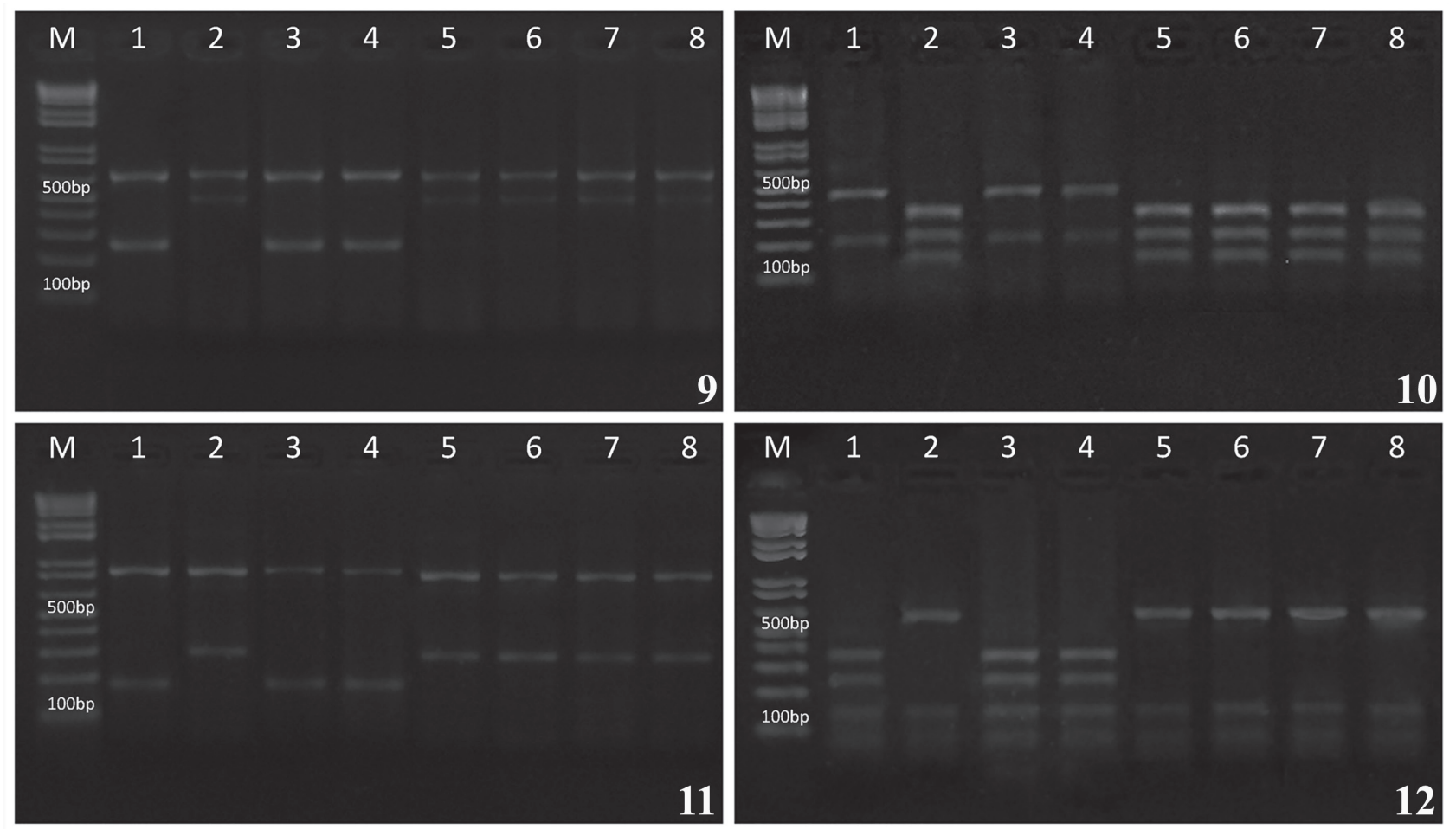

Figs 9-12. Fig. 9, patterns of PCR-multiplex for the COI mitochondrial gene. Fig. 10, PCR-RFLP patterns of the COI gene with NlaIV enzymes. Fig. 11, patterns of PCR-multiplex for the $R A G$ nuclear gene. Fig. 12, PCR-RFLP patterns of the RAG gene with the BsrI enzyme. The species are indicated as: column 1, Cichla kelberi Kullander \& Ferreira, 2006; column 2, Cichla piquiti Kullander \& Ferreira, 2006; column 3 and 4, Cichla kelberi; column 5 and 6, Cichla piquiti; column 7 and 8, carijó; M, 1 kb molecular weight marker. 


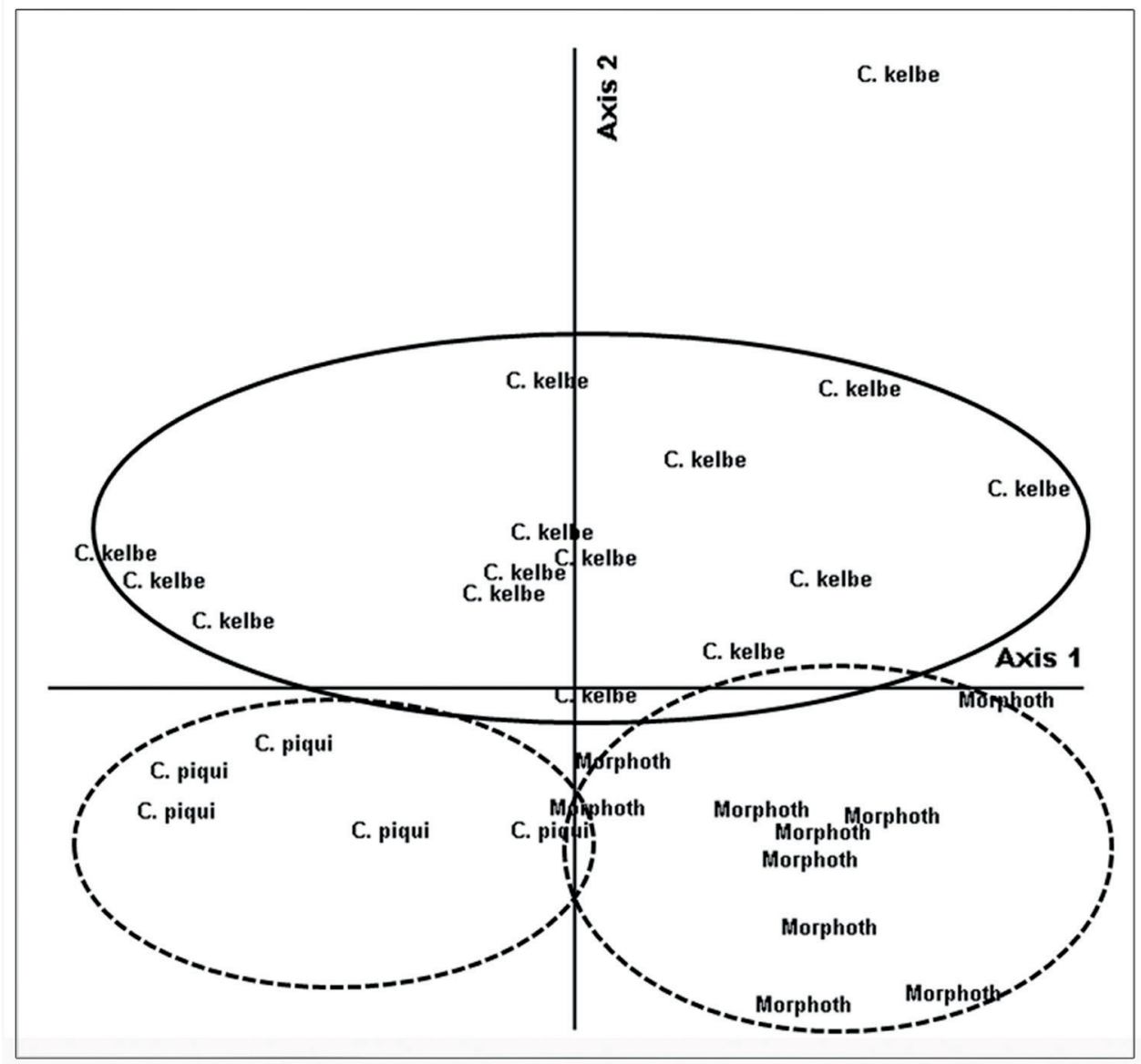

Fig. 13. Principal Component Analysis (PCA) for Cichla Bloch \& Schneider, 1801 specimens using morphological data. Highlight: Cichla kelberi Kullander \& Ferreira, 2006, Cichla piquiti Kullander \& Ferreira, 2006 and carijó samples distribution.

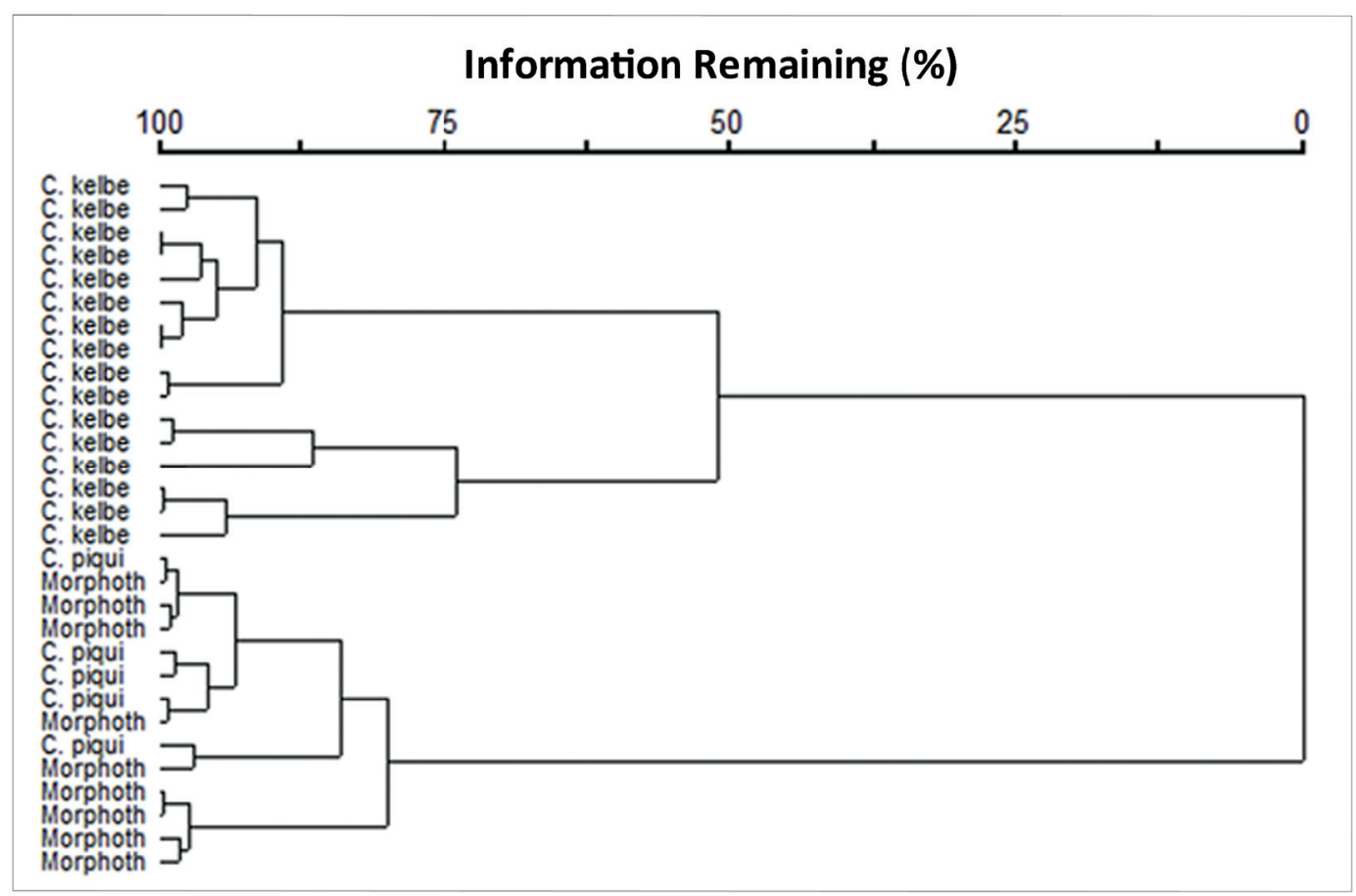

Fig.14. Cluster similarity based on the meristic data of Cichla Bloch \& Schneider, 1801 specimens, indicating the relationship among Cichla kelberi Kullander \& Ferreira, 2006, Cichla piquiti Kullander \& Ferreira, 2006 and carijó samples. 
hybridization occurring between the two studied species.

The genetic analyses performed in this study clearly differentiated C. kelberi from C.piquiti, but showed carijó as belonging to the $C$. piquiti species, because the electrophoretic profile of carijó was identical to that of $C$. piquiti. Besides that, the morphologic analysis revealed two groups, the $C$. kelberi cluster and the $C$. piquiti cluster. The $C$. kelberi cluster formed entirely by $C$. kelberi individuals and the $C$. piquiti cluster formed by two morphotypes, the $C$. piquiti itself and the carijó. Thus, both results support the carijó as morphotype of $C$. piquiti.

The morphotype confirmation has great biological value for the group because a hybridization confirmation has been a difficult and common problem for the conservation of fishes (Allendorf et al., 2001). Considering the high prolificity and the lentic environments adaptations of Cichla (GodinHo et al., 1994), hybridization could be even greater problem. However, studies that consider hybridizations among other species of the genus are of great value, because there are many cases already reported for the group (e.g. Alves \& FeldBerG, 1998; BrinN et al., 2004; OliveIRA et al., 2006; Oliveira et al., 2008; AlmeIDA-FERREIRA et al., 2011).

In general, this phenotypic changes occurred in morphotypes may be associated to agonistic behavior, spawning, sexual selection (BARLOw, 2000) or to sexual dimorphism (WINEMILLER, 2001; KULlANDER \& FERREIRA, 2006). According to Kullander \& Ferreira (2006) the juvenile and adult phases of Cichla have different colourations. Additionally, WinEMILLER (2001) describes distinct colourations in adults related to the different stages of gonadal maturation. In addition, the phenotypic changes may be associated to cannibalism inhibition (ZARET, 1977), predatory pressure (MAGURRAN, 2005), predatorprey interactions (MAAN \& SEFC, 2013) or, yet, to seasonal maturity in both sexes (REISs et al., 2012). In any case, the morphotypes presence is an event already observed in the genus Cichla (Winemiller, 2001; Reiss et al., 2012).

The present study does not question the reason for the Cichla morphotype appearing; it just describes and reports its existence in addition to test whether it constitutes a hybrid species. Studies that promote the understanding of the ecological and reproductive role of this morphotype and how the biotics and abiotics factors influence the appearing of morphotypes such as the carijó individuals are of broad interest. For example, different experiments investigating the hypothesis associated with the causes of morphotypes occurrence may include exposing C. kelberi, C. piquiti and carijó to: agonistic and spawning behavior, absence or presence of sexual selection, seasonal maturity, stage of maturation and reproduction and predatory pressure and interactions, among others.

The new molecular markers propose in the present study might be interesting taxonomically because is the first molecular identification tool developed for carijó individuals and the first document relating and analyzing the carijó. Therefore, these markers could be used for Cichla identification in future research, monitoring, management and conservation programs, because there are scarce studies assigned to the Neotropical cichlids biology, especially involving peacock bass, that has great socio-economic value.

Acknowledgments. The authors thank to the Dr. Francisco Langeani Neto for contributing with ideas and thoughtful comments on the manuscript and the Conselho Nacional de Desenvolvimento Científico e Tecnológico (CNPq) for financial support.

\section{REFERENCES}

Aboim, M. A.; Mavarez, J.; Bernatchez, L. \& Coelho, M. M. 2010. Introgressive hybridization between two Iberian endemic cyprinid fish: a comparison between two independent hybrid zones. Journal of Evolution Biology 23:817-828.

Agostinho, A. A.; Gomes, L. C. \& Pelicice, F. M. 2007. Ecologia e manejo de recursos pesqueiros em reservatórios do Brasil. Maringá, Eduem. 501p.

Allendorf, F. W.; Leary, R. F.; Spruell, P. \& Wenburg, J. K. 2001. The problems with hybrids: setting conservation guidelines. Trends in Ecology and Evolution 16(11):613-622.

Almeida-Ferreira, G. C.; Oliveira, A. V.; Prioli, A. J. \& Prioli, S. M. 2011. Spar genetic analysis of two invasive species of Cichla (Tucunaré) (Perciformes: Cichlidae) in the Paraná river basin. Acta Scientiarum, Biological Sciences 33(1):79-85.

Alves, M. N. \& Feldberg, E. 1998. Análise cariotípica no gênero Cichla e considerações evolutivas na família Cichlidae. In: VII Simpósio de Citogenética e Evolução Aplicada de Peixes Neotropicais. Londrina, C17.

BARLOW, G. W. 2000. The cichlid fishes: nature's grand experiment in evolution. Cambridge, Perseus Books. 352p.

Brinn, M. N. A.; Porto, J. I. R. \& FeldberG, E. 2004. Karyological evidence for interspecific hybridization between Cichla monoculus and Cichla temensis (Perciformes, Cichlidae) in the Amazon. Hereditas 141:252-257.

Carvalho, D. C.; Oliveira, D. A. A.; Sampaio, I. \& Beheregaray, L. B. 2014. Analysis of propagule pressure and genetic diversity in the invasibility of a freshwater apex predator: the peacock bass (genus Cichla). Neotropical Ichthyology 12:105-116.

Chevassus, B. 1983. Hybridization in fish. Aquaculture 33:245-262.

De-Franco, B.; MendonçA, F. F.; Oliveira, F. C. \& Foresti, F. 2012. Illegal trade of the guitarfish Rhinobatos horkelii on the coasts of central and southern Brazil: genetic identification to aid conservation. Aquatic Conservation: Marine and Freshwater Ecosystem 22:272-276.

FAlCONER, D. S. \& Mackay, T. F. C. 1996. Introduction to Quantitative Genetics. Essex, Longmans Green. 308p.

Godinho, A. L.; Fonseca, M. T. \& Araújo, L. M. 1994. The ecology of predator fish introductions: the case of rio Doce valley. In: PINTOCoelho, R. M.; Gianni, A. \& von Sperling, E. eds. Ecology and human impact on lakes and reservoirs on Minas Gerais, with special references to future development and management strategies. Belo Horizonte, SEGRAC, p. 77-83.

Gomes, F.; Schneider, H.; Barros, C.; Sampaio, D.; Hashimoto, D. T.; Porto-Foresti, F. \& SAMPAIO, I. 2012. Innovative molecular approach to the identification of Colossoma macropomum and its hybrids. Annals of the Brazilian Academy of Sciences 84:517-525.

Hall, T. A. 1999. BioEdit: a user-friendly biological sequence alignment editor and analysis program for Windows 95/98/NT. Nucleic Acids Symposium Series 41:95-98.

Hashimoto, D. T.; Mendonça, F. F.; Senhorini, J. A.; Bortolozzi, J.; Oliveira, C.; Foresti, F. \& Porto-Foresti, F. 2010. Identification of hybrids between Neotropical fish Leporinus macrocephalus and Leporinus elongatus by PCR-RFLP and multiplex-PCR: tools for genetic monitoring in aquaculture. Aquaculture 298:346-349.

Hashimoto, D. T.; Prado, F. D.; Senhorini, J. A.; Foresti, F. \& PortoFORESTI, F. 2012. Detection of post-F1 fish hybrids in broodstock using molecular markers: approaches for genetic management in aquaculture. Aquaculture Researches 44:876-884.

Hausdorf, B. 2011. Progress toward a general species concept. Evolution 65:923-931. 
Karlsson, S.; Hagen, M.; Eriksen, L.; Hindar, K.; Jensen, A. J.; Leaniz, C. G.; Cotter, D.; GuĐbergsson, G.; Kahilainen, K.; GuĐjónsson, S.; Romakkaniemi, A. \& Ryman, N. 2012. A genetic marker for the maternal identification of Atlantic salmon x brown trout hybrids. Conservation Genetic Resources 5:47-49.

Kullander S. O. 1986. Cichlid fishes of the Amazon river drainage of Peru. Sweden, Swedish Museum of Natural History. 431p.

Kullander, S. O. 2003. Family Cichlidae (Cichlids). In: ReIs, R. E; Kullander, S. O. \& Ferraris, C. L. eds. Check list of the freshwater fishes of the south and central America. Porto Alegre, Edipucrs, p.605-607.

Kullander, S. O. \& Ferreira, E. J. G. 2006. A review of the South American cichlid genus Cichla, with description of nine new species (Teleostei: Cichlidae). Ichthyology Exploration Freshwaters 17:289398.

Kullander, S. O. \& NiJssen, H. 1989. The cichlids of Surinam: Teleostei, Labroidei. Leiden, E. J. Brill. 256p.

Latini, A. O. \& Petrere Jr, M. 2004. Reduction of a native fish fauna by alien species: an example from Brazilian freshwater tropical lakes. Fish Manage Ecology 11:71-79.

MAAN, M. E. \& SEFC, K. M. 2013. Colour variation in cichlid fish: Developmental mechanisms, selective pressures and evolutionary consequences. Seminars in Cell and Developmental Biology 24:516528.

Magurran, A. E. 2005. Evolutionary ecology: The Trinidadian guppy. ISBE Newsletter 19:25-26.

Mallet, J. 2005. Hybridization as an invasion of the genome. Trends in Ecology and Evolution 20:229-237.

MAYr, E. 1942. Systematics and the origin of species, from the viewpoint of a zoologist. Cambridge, Harvard University Press. $808 \mathrm{p}$.

MAYR, E. 1963. The breakdown of isolating mechanisms (hybridisation). In: MAYr, E. ed. Animal Species and Evolution. Cambridge, Belknap Press, p.110-135.

Mccune, B. \& Mefford, M. J. 2006. PC-Ord: Multivariate Analysis of Ecological Data, version 5.31. Gleneden Beach, MjM Software. Available at $<$ https://www.pcord.com/ $>$.

Millar, M. A.; Byrne M.; Nuberg, I. K.; \& Sedgley, M. 2012. High Levels of Genetic Contamination in Remnant Populations of Acacia saligna from a Genetically Divergent Planted Stand. Restoration Ecology 20(2):260-267.

Oliveira, V. F.; Oliveira, A. V.; Prioli, A. J. \& Prioli, S. M. 2008. Obtaining 5S rDNA molecular markers for native and invasive Cichla populations (Perciformes- Cichlidae), in Brazil. Acta Scientiarum, Biological Sciences 30(1):83-89.

Oliveira, A. V.; Prioli, A. J.; Prioli, S. M. A. P.; Bignotto, T. S.; Júlio Jr, H. F.; Carrerk, H.; Agostinho, C. S. \& Prioli, L. M. 2006. Genetic diversity of invasive and native Cichla (Pisces: Perciformes) populations in Brazil with evidence of interspecific hybridization. Journal of Fish Biology 69(B):260-277.
Pelicice, F. M. \& Agostinho, A. A. 2009. Fish fauna destruction after the introduction of a non-native predator (Cichla kelberi) in a Neotropical reservoir. Biological Invasions 11:1789-1801.

Prado, F. D.; Hashimoto, D. T.; Mendonça, F. F.; Senhorini, J. A.; Foresti, F. \& Porto-Foresti, F. 2011. Molecular identification of hybrids between Neotropical catfish species Pseudoplatystoma corruscans and Pseudoplatystoma reticulatum. Aquaculture Research 42:1890-1894.

Prado, F. D.; Hashimoto, D. T.; Senhorini, J. A.; Foresti, F. \& PortoForesti, F. 2012. Detection of hybrids and genetic introgression in wild stocks of two catfish species (Siluriformes: Pimelodidae): The impact of hatcheries in Brazil. Fisheries Research 125-126:300-305.

Reiss, P.; Able, K. W.; Nunes, M. S. \& HrbeK, T. 2012. Colour pattern variation in Cichla temensis (Perciformes: Cichlidae): Resolution based on morphological, molecular and reproductive data. Neotropical Ichthyology 10:59-70.

SAmpaio, W. M. S.; Belei, F.; Giongo, P. \& Silva, W. L. 2012. Ichthyofauna, Uberabinha River (Upper Paranaíba River Basin), Triangle Mineiro region, Uberlândia, Minas Gerais, Brazil. Check List 8: 1085-1088.

Scribner, K. T.; PAge, K. S. \& Bartron, M. L. 2001. Hybridization in freshwater fishes: a review of case studies and cytonuclear methods of biological inference. Reviews in Fish Biology and Fisheries 10:293323.

Thompson, J. D.; Higgins, D. G. \& Gibson, T. J. 1994. CLUSTAL W: improving the sensitivity of progressive multiple sequence alignment through sequence weighting, positions-specific gap penalties and weight matrix choice. Nucleic Acids Research 22:4673-4680.

Thresher, R. E.; Hayes, K.; Bax, N. J.; Teem, J.; Benfey, T. J. \& Gould, F. 2014. Genetic control of invasive fish: technological options and its role in integrated pest management. Biological Invasions 16:1201-1216.

Toledo-Filho, S. A.; Almeida-Toledo, L. F.; Foresti, F.; Calcagnotto, D.; Santos, S. B. A. F. \& Bernardino, G. 1998. Programas genéticos de seleção, hibridação e endocruzamento aplicados à piscicultura. Cadernos de Ictiogenética IV:1-53.

VincZE, T.; POSFAI, J. \& RoBERTS, R. J. 2003. NEBcutter: a program to cleave DNA with restriction enzymes. Nucleic Acids Research 31:3688-3691.

Willis, S. C.; Macrander, J.; Farias, I. P. \& Orti, G. 2012. Simultaneous delimitation of species and quantification of interspecific hybridization in Amazonian peacock cichlids (genus Cichla) using multi-locus data. BMC Evolutionary Biology 12:1-24.

Winemiller, K. O. 2001. Ecology of peacock Cichlids (Cichla spp.) in Venezuela. Journal of Aquaculture and Aquatic Sciences 9:93-112.

Young, W. P.; Ostberg, C. O.; Keim, P. \& Thorgandd, G. H. 2001. Genetic characterization of hybridization and introgression between anadromous rainbow trout (Oncorhynchus mykiss irideus) and coastal cutthroat trout (O. clarki clarki). Molecular Ecology 10:921-930.

ZARET, T. M. 1977. Inhibition of cannibalism in Cichla ocellaris and hypothesis of predator mimicry among South American fishes. Evolution 31:421-437. 